Sigve Ladstein er førstelektor i naturfag ved NLA Høgskolen avd. for lærerutdanning hvor han under-

viser GLU- og BL studenter. Hans forskningsinteresser er naturfagdidaktikk, nettstudier og moleky-

lærbiologi. Ladstein har arbeidet med å styrke naturfag i barnehagelærerutdanningen og inspirere til

naturfaglig arbeid $\mathrm{i}$ barnehagen. Han har også undersøkt hvordan det tverrfaglige emnet teknologi og

design ble innført i ungdomsskolen.

\title{
Læreres erfaringer med teknologi og design i ungdomsskolen i møte med ny læreplan i Norge
}

\section{INNLEDNING}

\section{Bakgrunn og motivasjon}

Teknologi og design har vært et hovedområde i naturfag siden gjeldende læreplan for norsk grunnskole ble innført i 2006 (Kunnskapsløftet, forkortet LKo6) (KD, 2006). Undervisning i det tverrfaglige emnet skulle være et samarbeid mellom naturfag, kunst og håndverk og matematikk (ibid). Denne artikkelen presenterer viktige deler av den lange prosessen som banet vei for teknologi frem til LKo6. Gjennom synspunkter fra (natur)faglige utvalg, statlige prosesser og andre aktører, var det ønskelig å identifisere intensjoner med teknologi og design som ble lagt til grunn for emnet i LKo6. Mot denne bakgrunn ble lærere intervjuet for å belyse deres oppfattelse av intensjonen med emnet, og skaffe et dypere innblikk i hvordan de planla og gjennomførte undervisning i teknologi og design. Resultatene viser hvordan informantene forholdt seg til kompetansemål, hvilke målsetninger de hadde med undervisning, planlegging utdypes, og de konkretiserer undervisning. Et sentralt anliggende var også å avdekke i hvilken grad lærerne arbeidet tverrfaglig med teknologi og design. Kan vi deretter finne ut noe om forholdet mellom intensjonene med teknologi og design og virkeligheten slik den fremtrer fra et lærerperspektiv?

Det pågår nå en nasjonal fagfornyelse av Kunnskapsløftet hvor det er utredet og besluttet at tre tverrfaglige temaer skal undervises i flere fag (KD, 2016, 2018). Det kan spørres i hvilken grad læreres erfaring med teknologi og design gir støtte for en læreplanendring med økt omfang av tverrfaglig undervisning. Denne studien undersøker hvordan det tverrfaglige emnet teknologi og design, ifølge lærere, gjennomføres i ungdomsskolen. For å belyse problemstillingen ble følgende forskningsspørsmål stilt: 1) Hva oppfatter lærere i ungdomsskolen som hensikten med teknologi og design, 2) hva kjennetegner ifølge lærerne planlegging og undervisning i emnet, og 3) i hvilken grad forekommer tverrfaglig samarbeid i teknologi og design ifølge lærerne?

\section{Teknologi og design i norsk grunnskole}

Prosessene som ledet til vinklingen teknologi og design fikk i LKo6 var inspirert av faget Design \& Technology i England, hvor teknologifaget hadde svak relasjon til naturvitenskap i skolen (Bungum, 2006). I Norge er teknologi og design et tverrfaglig emne gjennom hele grunnskolen, og emnet fremtrer tydelig i naturfag sin læreplan hvor teknologi og design er et hovedområde med spesifikke kompetansemål. Kunst og håndverk og matematikk er de andre skolefagene i trepartssamarbeidet, hvor kunst og håndverk skal bidra med «det praktisk-estetiske aspektet ved design» (KD, 2006, s. 129). 
Kunst og håndverk har kompetansemål i arkitektur og design, hvor det siste området har læringsmål relevant for teknologi og design. Matematikk er beskrevet som et redskapsfag i arbeidet med teknologi og design (ibid, s. 57). I læringsarbeidet skal elevene designe, utvikle og vurdere produkter, evaluere designprosessen og lære om ulike materialer og deres bruksområder. I Norge er altså teknologi tydelig integrert i læreplan for naturfaget. Det samsvarer med Fensham og Gardner (1994) sin «partnerskap» beskrivelse av relasjonen, hvor undervisning av teknologi og naturvitenskap er likestilt og avhengig av hverandre.

Til å forstå hvilke formål staten hadde med teknologi og design, slik det uttrykkes i LKo6, er det nødvendig å undersøke hvilke og hvordan forskjellige aktører påvirket utviklingen som ledet til emnet. Hvilke interesser, som av Goodlad karakteriseres som den ideologiske læreplanen (Goodlad, Klein \& Tye, 1979), banet vei for teknologi i norsk skole?

Naturfagutredningen avdekket at det knapt ble undervist i naturfag på barnetrinnet, og elever møtte ikke teknologi, i naturfaget, før på ungdomstrinnet (Sjøberg, 1994). Noen læreverk ble rapportert å være uegnet for undervisning i naturfag da de hadde faglige svakheter og noen formidlet en negativ holdning til naturvitenskap og teknologi. En stor andel av lærerne som underviste i naturfagene hadde heller ikke tilstrekkelig naturfaglig kompetanse (ibid). Utvalget påpekte at grunnskolens naturfag var i krise og anbefalte at teknologi burde få en tydelig plass i den kommende skolereformen fra 1997. I Sverige ble innføringen av teknologi i grunnskolen betraktet som medisin mot den såkalte naturvetarkrisen (Riis, 2013). Teknik ble I Sverige et obligatorisk grunnskoleemne i 1982 og et selvstendig fag fra 1994, i en periode hvor mange land implementerte teknologi i grunnopplæringen (Ginner \& Mattsson, 1996; Jones, Buntting \& de Vries, 2013; Riis, 1996).

Den generelle læreplanen (L93, som fremdeles er gjeldende) viste hvorfor teknologi og skapende arbeid er nødvendig for samfunnsutviklingen og understrekte hvor sentral opplæring i teknologisk kunnskap er i en allmenndannende skole (KUF, 1993). Dahlin, Svorkmo og Voll (2013) fremhevet at L93 gir en dekkende beskrivelsen av hvilken teknologi- og designkompetanse elever trenger. Den generelle læreplanen kunne dermed oppfattes å være en statlig døråpner for det som kunne blitt læreplanfestet undervisning i teknologi og design i den norske skolereformen fra 1997. Men den nye læreplanen, L97 (KUF, 1996), bygget i liten grad på L93 når det gjaldt fokus på teknologi i opplæringen. L97 fulgte heller ikke opp naturfagutredningen (Sjøberg, 1994) eller forventninger fra det statlige langtidsprogrammet hva angår styrking av teknologi i naturfaget (FT, 1993).

Departementet (KUF) nedsatte i 1996 Tveitereidutvalget som fortsatte elendighetsbeskrivelsen fra naturfagutredningen ved å tydeliggjøre gapet mellom utdanningsnivå og teknologiske kompetanse som trengs for å kunne delta i samfunnet og sikre verdiskaping. Påfølgende år, samtidig med at L97 ble gjeldende for norsk skole, la utvalget frem en tiltakspakke med økt satsing på naturvitenskap, matematikk og teknologi (Tveitereid, 1997). Et dristig forslag fra utvalget om å innføre et eget fag i grunnskolen, kalt teknologi og formgivning, kunne gitt gode og varige ringvirkninger i befolkningen. Mye lå dermed til rette for skolemyndighetene til å revitalisere naturfaget i L97, og gi teknologisk kunnskap og ferdigheter et solid innhold og tilstrekkelig omfang. Det startet da også bra med fokus på teknologi gjennom innledningen til planen for natur- og miljøfag (som da ble navnet på naturfag i norsk grunnskole), samt i overordnet mål for faget (KUF, 1996). Men, når en studerer hovedmomentene elevene skulle arbeide med i teknologi på ungdomstrinnet dominerte en historisk teoripreget tilnærming til kunnskapsområdet (KUF, 1996). Det var underlig at elevene ikke fikk erfaring med praktisk og skapende prosesser som kjennetegner teknologisk kunnskap og utvikling (McCormick, 1997). Avstanden mellom intensjoner og formell læreplan var betydelig på det teknologiske området og norsk grunnskole var langt fra å erkjenne virkeligheten som beskrevet (KUF, 1993; Sjøberg, 1994; Tveitereid, 1997).

Norges ingeniørorganisasjon (NITO) startet prosjektet Teknologi i Skolen, samme år som L97 ble innført, for å utvide elevene sin teknologikompetanse og styrke søkertallene til teknologisk utdan- 
nelse. Prosjektet må i ettertid sies å være en av premissleverandørene til dagens teknologi og design (Hansen, 2007), da særlig ved å vektlegge praktisk arbeid og estetisk utforming i skapende prosesser.

Hvilke konsekvenser fikk innføringen av natur- og miljøfaget i L97 for elever sin naturfagskompetanse og Teknologi i Skolen sin satsing på teknologi gjennom kursing av lærere? Kvalitetsutvalget påpekte at naturfagkompetansen fremdeles var synkende blant norske elever, noe som kom til uttrykk i urovekkende svake prestasjoner i internasjonale sammenligninger (TIMMS og PISA) (UFD, 2003). Det var også bekymringsfullt at rekrutteringen til realfag var svak (ibid). Utvalget viste også til strategi for styrking av realfagene som var et ekko av tidligere beskrivelser: timetallet i realfag var lavt, natur- og miljøfag var omfattende og realfagene opplevdes uinteressante (UFD, 2002). Kvalitetsutvalget ble særlig bedt om å sette realfag under lupen og da var det underlig, men interessant, at det mest konkrete i naturfaglig retning var forslaget om at teknologi og design burde etableres som eget fag på ungdomstrinnet (UFD, 2003). Faget skulle motvirke synkende kompetanse i realfagene og styrke fokuset på teknologi (ibid). Kvalitetsutvalget vektla også elevaktive arbeidsformer for å øke elevenes læring i natur- og miljøfaget (UFD, 2003), men burde gått dypere i analysen av problembeskrivelsen og fremmet flere tiltak, som kunne styrket opplæringen i naturfagene.

Stortingsmeldingen Kultur for læring (KUF, 2004a), som var det viktigste grunnlagsdokumentet for LKo6, fulgte ikke opp Kvalitetsutvalgets forslag om teknologi og design som eget fag i grunnopplæringen. Men, det inkluderes en evaluering av natur- og miljøfaget, som ble behandlet av Kvalitetsutvalget, hvor betydningen av praktisk arbeid fremheves (Almendingen, Klepaker \& Tveita, 2003). Stortingsmeldingen opplyser at høringsinstansene ønsket teknologi og design på ungdomstrinnet, men oppgav ikke direkte hvor mange som ville ha emnet som et eget fag. Saken fremlegges endelig i meldingen på en måte som støttet departementets konklusjon om å innføre teknologi og design som et tverrfaglig emne, med egne kompetansemål, i den kommende læreplanen. Bungum (2006) viser at kultur- og samfunnsaspekter ved teknologi også preger læreplanen for naturfag, men disse synes ikke å være de sterkeste drivkreftene for innføringen av teknologi og design i LKo6. Det argumenteres med at teknologi og design vil gjøre de ansvarlige fagene mer praktiske og øke deres nytteverdi (KUF, 2004a).

I en nyere studie verdsettes praktisk arbeid i teknologi og design, men få av lærerne tror emnet kan øke rekrutteringen til teknologiske studier (Dundas, 2011). Denne studien finner også tegn til at det ikke undervises så mye i teknologi og design som en kunne forvente, og rapporterer om dårlige vilkår for kollegasamarbeid som grunnlag for tverrfaglig undervisning. Utdanningsdirektoratet sin evaluering av LKo6 påpeker at det skolefaglige innholdet i fagene skiller seg lite fra tidligere reformer, og at klasseromspraksisen synes å være uendret etter innføringen av LKo6 (Udir, 2012). Elevene er imidlertid fornøyd med undervisningen og de er spesielt positive til forsøk i naturfag eller annet praktisk rettet arbeid som gjør skolearbeidet mer konkret (Udir, 2012, s. 9). Det er lite spesifikt å finne om teknologi og design, bortsett fra at lærerne oppgir at økt metodefrihet i LKo6 kan ha medført mindre tverrfaglig arbeid og større fokus på enkeltfag (Hodgson, Rønning \& Tomlinson, 2012, s. 13). Dette er dårlige nyheter for å kunne realisere intensjonene med teknologi og design (KD, 2013) og det gir begrenset optimisme for å øke omfanget av tverrfaglig undervisning i den kommende skolereformen (KD, 2016). En nylig rapport foreslår at teknologi innføres som et eget obligatorisk fag i grunnskolen (Sanne et al., 2016). Rapporten anbefaler at teknologifaget fremstår selvstendig i læreplanen, og ikke som en integrert del av andre fag, som gjerne fører til at teknologien forsvinner.

Ludvigsen-utvalget identifiserte noen fagovergripende kompetanseområder som burde synliggjøres i ny læreplan for fagene (KD, 2015). Utvalget anbefalte også tre tverrfaglige tema som særlig viktige i fremtidens grunnopplæring. Disse gjenkjennes i kjerneelementer og er tydelige i utkast til nye læreplaner i flere fag (KD, 2018; Udir, 2019). Ludvigsen-utvalget påpeker at tverrfaglig undervisning kan fremme dybdelæring og antyder at arbeidsmåten kan øke elevene sin forståelse av komplekse sammenhenger og sammenhenger mellom fag (KD, 2015). Utvalget viser hvordan den nåværende faginndelingen kan hindre tverrfaglig undervisning og mener fagtrengselen i skolefagene må reduseres til prioritering av sentralt faglig innhold, de såkalte kjerneelementer eller big ideas (Harlen, 2015; KD, 2016). 
Ansporingene til en skolehverdag med mer tverrfaglig organisering og undervisning ble i stor grad videreført i stortingsmeldingen for den kommende skolereformen (KD, 2016). I forslag til ny læreplan er det tverrfaglige teknologi og design fjernet, og teknologi er blitt et kjerneelement i naturfag med til dels nye kompetansemål (Udir, 2019). Design er ivaretatt av kunst og håndverk. Dersom skolereformen som skal tre i kraft høsten 2020, i sin endelige utforming, innebærer mer tverrfaglig undervisning enn i dag, oppstår et påtrengende spørsmål: vil den norske skolen med sine enfaglige tradisjoner og lærere som er utdannet og sosialisert inn i denne tradisjonen, samt andre begrensende faktorer, være rede for en så betydelig omlegging? Erfaringer med lærerplanlegging og gjennomføring av det tverrfaglige emnet teknologi og design, presentert i denne studien, gir også noen perspektiver på den problemstillingen.

\section{METODE}

\section{Datainnsamling}

Artikkelen bygger på semistrukturerte kvalitative intervjuer (Kvale \& Brinkmann, 2009) ledsaget av en intervjuguide (Fontana \& Frey, 2000) med syv hovedtema. Det ble vektlagt at informantens synspunkter skulle komme klart frem uten påvirkning gjennom ledende spørsmål eller egne meninger. Av samme grunn ble heller ikke intervjuguiden utsendt til informantene i forkant av intervjuet, for å unngå at de kunne svare slik de trodde intervjuer ønsket.

Informasjon fra fem hovedtema med flere oppfølgerspørsmål behandles i denne artikkelen: bakgrunnsvariabler (1), informanten sin oppfattelse av intensjonen med teknologi og design (2), informanten sine målsetninger med undervisning i teknologi og design (3), forarbeid og fokus på kompetansemålene i LKo6 (4) og informanten sin beskrivelse av undervisningen i teknologi og design (5). Hovedtema en gav opplysninger om utdannelse, erfaring med teknologi og design, trinnplassering og vektlegging av emnet ved skolen der informanten arbeider. Under hovedtema fire forklarte informantene hvordan de planla undervisning og bruken av aktuelle kompetansemål i den sammenheng.

\section{Utvalg av informanter og gjennomføring av intervju}

Kriterier for å velge ut informanter var at lærerne gjerne skulle ha undervist fem år i naturfag på ungdomsskolen, og de burde undervise i teknologi og design inneværende år eller hatt teknologi og design etter innføringen av LKo6. Fem lærere fra fem ungdomsskoler i fire ulike kommuner på Vestlandet ble intervjuet. Et forholdsvis lite utvalg av informanter begrenser slutningene, men uttømmende intervjuer gav et fyldig datagrunnlag for å belyse forskningsspørsmålene. Lærerne fordelte seg på en byskole, tre skoler i tettbygde kommunesentre og en skole fra område med spredt bebyggelse. En kvinne og fire menn ble intervjuet og undervisningsansienniteten varierte fra 3 - 30 år. Av informantene var tre allmennlærere og to lektorer med hovedfag fra Universitet, hvorav tre hadde formell videreutdannelse i naturfag. En av intervjupersonene hadde gjennomført didaktisk kurs med innhold relevant for undervisning i teknologi og design. Allmennlærerne i denne studien syntes å representere lærere med god forståelse og engasjement for undervisning i teknologi og design. Lektorene vil da kunne sies å representere lærere med mindre forståelse og engasjement for teknologi og design i grunnskolen.

Intervjuene varte i 45 minutter og ble i hovedsak gjennomført ved informantene sine skoler. Informantene samtykket til å delta og de ble informert om at de når som helst kunne trekke seg fra studien. Intervjuene inviterte ikke informantene til å gi opplysninger om enkeltelever, lydopptak av intervjuer ble slettet når studien var avsluttet, og behandling av datamateriale er gjort i henhold til krav fra norsk samfunnsvitenskapelig datatjeneste. Lydopptakene av intervjuene ble transkribert ved bruk av Transana versjon 2.42 (2018) og alle transkripsjonene ble skrevet på bokmål for å sikre anonymiteten til informantene. Transkripsjonene ble utformet ordrett for i størst mulig grad å ivareta innhold og informanten sin mening fra det som ble sagt. Navn som blir brukt på informantene i denne artikkelen er fiktive (Leif, Johan, Margun, Oscar og Gudmund) og forskningsprosjektet er godkjent av norsk samfunnsvitenskapelig datatjeneste. 


\section{Kvalitetssikring og behandling av data}

To forskere bidrog i en grundig vurdering av hvordan spørsmålene i intervjuguiden kunne oppfattes, for å sikre at spørsmålene kunne gi rikelig informasjon for å belyse forskningsspørsmålene. Denne kvalitetssikringen styrker validiteten til studien. For å øke påliteligheten til empirien var jeg nøye med å be informantene utdype grunne svar. Det gav utfyllende beskrivelser av informantene sine synspunkter og en større helhetlig forståelsen av punkter i intervjuguiden. Siden hovedtemaene i intervjuguiden ligger tett opptil forskningsspørsmålene for studien ble det valgt å systematisere data fra informantene som belyser det enkelte hovedtema (1-5 over). Mulighet til oppfølgerspørsmål under intervjuene gav utfyllende beskrivelser av informantene sine synspunkter som styrker validiteten til datamaterialet. Kategorisering av datamaterialet ble gjennomført med grundig inspeksjon av de transkriberte intervjuene og samling av tekstbiter som belyser hovedtemaene. Informantene sine svar på samme oppfølgerspørsmål ble gruppert i underkategorier, sammenlignet, og gir grunnlag for drøfting. I den videre analysen er resultatene sett i lys av litteratur om bakgrunnen for og intensjonen med teknologi og design i LKo6. Forskning om teknologi i skolen og Goodlad et al. (1979) sin læreplanteori benyttes også i analysen.

\section{RESULTAT}

Som vi har sett var det blant annet uttrykt ønske om at teknologi og design skulle heve kvaliteten på grunnskolens naturfag og motivere elever til å satse på utdanning i realfag (Bungum, 2006; Sjøberg, 1994; Tveitereid, 1997). Hva oppfatter så ungdomsskolelærere som hensikten med teknologi og design? Vil synspunktene sammenfalle med eller avvike fra intensjonene og kan lærernes erfaringer gi noen perspektiver på den kommende læreplanendringen i norsk grunnskole?

\section{Fra ideologisk til oppfattet Iæreplan}

Margun uttaler at «en har behov for flere med realfagskompetanse i samfunnet» og mener en årsak til å ha teknologi og design i læreplanen er at flere elever skal velge en utdannelse relatert til teknologi og design. Disse synspunktene støtter strategiplanen for naturfag hvor det fremkommer at få norske ungdommer kan tenke seg en jobb innenfor naturvitenskap eller teknologi (UFD, 2005). Margun understreker også at det kan vekkes en interesse for teknologi og design hos elever som ikke er så begeistret for tematikken. Margun synes å tenke på at arbeidsmåtene som brukes i teknologi og design kan fremme glød og økt forståelse for teknologi hos elever som ikke har noe forhold til emnet.

Gudmund mener teknologi og design «er en måte å kople sammen naturvitenskap og forskning» for å løse samfunnsbehov og konkretiserer disse til å finne løsning på ressursbruk generelt og energiproblemer spesielt. Han påpeker at «en ganske stor del av utviklingen fremover krever teknologi og design» og uttrykker at skolemyndighetene ønsker elever som kan skape nye arbeidsplasser. Synspunktene samsvarer med Frank Banks (1996) fjerde argument for teknologiopplæring i skolen.

Oscar nevner at teknologi og design ble innført i LKo6 «fordi det har vært en rivende utvikling teknologisk sett. Og at en ser at ny teknologi (..) gir nye muligheter». Dette kan tolkes dit at han mener elevene sin opplæring i teknologi skal gi de muligheter til å bli aktive deltakere i kunnskapssamfunnet. Johan ser potensialet for at emnet kan vekke en forskertrang hos elevene. Det kan likevel spørres om vinklingen teknologi og design har hatt i LKo6 (KD, 2006, 2013) har vært et tilstrekkelig springbrett mot et høyteknologisk samfunn.

Oscar er den informanten som er mest spørrende til teknologi og design. Han opplever intensjonen med emnet som god, men synes det er for lite tid til å gjennomføre undervisning slik en burde. Oscar ser potensialet til å heve kvaliteten på egen undervisning, særlig dersom skolen hans hadde fătt til tverrfaglig undervisning sammen med kunst og håndverk. Informanten peker også på egen manglende kompetanse som en årsak til at undervisningen ikke har et tilstrekkelig relevant innhold. Mangelen på kvalifiserte lærere i teknologi og design var trolig en av årsakene til at emnet ikke ble et nytt fag i LKo6 (Hansen, 2007). En av informantene i denne studien hadde ett kurs hvor noe av 
innholdet ble oppgitt å være relevant for teknologi og design, men flertallet uttrykte behov for å øke egen kompetanse på fagfeltet. Dette er en beskrivelse som også er kjent fra Sverige (Gustafsson, Jonsson \& Nilsson, 2018), hvor det er dokumentert at mange lærere ikke liker å undervise i teknologi som fører til en nedprioritering av emnet (Skolinspektionen, 2014). Fire av fem informanter var utdannet før LKo6 ble innført og de fleste lærerutdannerinstitusjoner gav trolig ikke opplæring i teknologi og design før grunnskolelærerreformen fra 2010. Trolig har lærerutdanningene bidratt positivt på kompetansenivået de siste årene.

\section{Planlegging av undervisning i teknologi og design}

For å få et utfyllende bilde av hvordan informantene arbeider med teknologi og design, ble det stilt en del spørsmål om undervisningsplanlegging. Flere av informantene opplyser at de bruker læreverket og finner praktiske oppgaver, filmer og bilder på internett. Margun bruker læreboken TELLUS (Ekeland, Hesenget, Johansen, Rygh \& Busengdal Strand, 2006-2008) og synes den har gode oppgaver og er en fin støtte for elevene i undervisningen. Hun filtrerer vekk lærestoff som er for avansert eller for lett for elevene, men søker også alternativt lærestoff på nettet. Margun stoler fullt og helt på lærerveiledningen. Grunnen til det er ifølge hun selv at hun ikke har jobbet så lenge og opplever at læreverket er nødvendig støtte. Det kan synes som at Margun er noe usikker på egen kompetanse og trenger tips til undervisningen. Gudmund fremhever at TELLUS har gode nettressurser (Lokus, 2018), men synes ikke læreverket er til hjelp i forarbeidet til undervisning. Gudmund uttaler at læreboken ikke har så mye lærestoff om teknologi og design, og at det trolig var fra tilfeldige Google søk han fant informasjon om brobygging som læringsaktivitet. Naturfagsenteret sine nettsider (2018), og særlig naturfag.no, har mye aktuelt stoff ifølge Gudmund.

Oscar og Johan oppgir kontant at de bruker læreboken som utgangspunkt for undervisning. Oscar sier «jeg har noen Power Point presentasjoner som jeg bruker» som også henter innhold fra lærerveiledningen, leksikon og YouTube. Oscar forteller at han planlegger teoretisk undervisning og elevene skal ikke gjøre praktisk arbeid slik LKo6 beskriver. Oscar avslører at planleggingen preges av hans syn på teknologi og design som mindre sentralt enn andre emner:

jeg har rett og slett ikke sett på dette som en så viktig del av pensum atjeg bruker ekstra tid, for da ville det kommet til fortrengsel for andre ting jeg anser som enda viktigere for den generelle utdannelsen videre (Oscar)

Jeg oppfatter Oscar til å velge en undervisning som sannsynligvis ikke er så motiverende for elevene. Johan har en del diffuse refleksjoner rundt teknologi og design, fra bygging av krabbeteiner og dyrefeller, til aerodynamikk hos biler og vindmøller. Ideene, som jeg oppfatter oppstår i intervjusituasjonen, kunne kanskje utvikles til konkret læringsarbeid, men også Johan velger teoretisk samtalebasert undervisning. Fra disse beskrivelsene vil det ikke overraske om elevene synes undervisningen er noe ensformig og den er et langt stykke fra den formelle læreplanen (KD, 2013). Oscar og Johan avslører manglende kjennskap til hva teknologi og design er ment å være, og virker lite motivert for å endre sin undervisningspraksis.

Leif og Gudmund lager en tydelig plan med en praktisk oppgave som elevene skal arbeide med. Leif avklarer for elevene hva teknologi og design er, hvilke læringsmål de skal forholde seg til, og tidsbruken på oppgaven. Informanten sier at en god plan sikrer ønsket utvikling i prosjektet. Gudmund opplyser at de viktigste forberedelsene er å «finne gode prosjekter eller gode elevaktiviteter». Dette får han ikke så mye tid til, så tidligere undervisningsplaner resirkuleres forholdsvis ukritisk.

\section{Bruk av kompetansemålene til planlegging}

Jeg var interessert i hvilken grad informantene forholdt seg til kompetansemålene fra LKo6 i planlegging av undervisning. Alle lærerne, unntatt Johan, oppgir at de på en eller annen måte vier kompetansemålene oppmerksomhet. Leif lager halvårsplaner og da blir relevante kompetansemål koplet til emner som undervises. Margun informerer om at kompetansemålene etter 10. trinn finnes i res- 
surspermen til TELLUS og at disse er fordelt over tre år og relatert til aktuelle lærebokkapitler. Under en gjennomgang av kompetansemålene sier Margun at det er kulepunkt to om å «teste og beskrive egenskaper ved materialer» (KD, 2006, s. 90) som de har jobbet mest med.

Gudmund sier «kanskje jeg ser litt på kompetansemålene» og gir også inntrykk av å ha et avslappet forhold til den lokale læreplanen når det fremkommer at «i naturfag så er det ikke akkurat den jeg ser på så veldig ofte». Oscar opplyser at kompetansemålene legges ut på nettsiden til skolen og elevene får dem utlevert. Informanten starter hvert lærebokkapittel med å presentere kompetansemålene og presiserer for elevene hva de skal lære, men han er usikker på om elevene forstår hva som menes med kompetansemål. Oscar signaliserer med dette at han ikke tror kompetansemålene har noen særlig betydning for elevene sin motivasjon og læring. Lærerne i denne undersøkelsen reflekterer i liten grad over sammenhengen mellom kompetansemålene i teknologi og design og undervisningen elevene får. Basert på hva informantene sier synes avstanden mellom formell og gjennomført læreplan betydelig (Goodlad, 1979), og det er grunn til å anta at elever ikke når alle kompetansemålene for teknologi og design gjennom opplæringen.

\section{Målsetninger for undervisningen}

Et hovedtema i intervjuguiden hadde som formål å danne en forståelse av hvilke målsetninger informantene hadde med undervisningen og hva de ønsket elevene skulle lære. Informantene bruker begreper som gøy, artig, glede, begeistring og undring når de beskriver hva de ville oppnå med undervisningen. Informantene vektlegger at elevene skal oppleve læringsprosessen som lystig og inspirerende, og de mener det kan styrke elevenes læringsutbytte.

Leif vektlegger elevene sitt gruppesamarbeid og mener det er viktig at de bruker ressursene i gruppen for å drive skaperprosessen. Leif synes prosessen er viktigere enn selve resultatet. Elevene sitt skapende arbeid fra idé til produkt er en sentral del av designprosessen (Dahlin et al., 2013) som trengs for å løse praktiske problemer og stimulere innovasjon og entreprenørskap i samfunnet. Samtidig skal en ikke undervurdere betydningen av flid og holdninger til å lage kvalitetsprodukter. Ingen informanter i denne studien reflekterer rundt de aspektene. Dette er forhold som kan være vanskeligere å fastholde i en tid preget av flyktighet og svekket kompetanse for håndverksarbeid hos elever (ibid).

Leif ønsker også at elevene skal lære praktisk arbeid ved å jobbe med hendene, og mener de kan dra nytte av erfaringen videre i livet. Opplæring i praktiske ferdigheter og erfaring med å bruke verktøy styrker elevenes evne til å løse utfordringer, og elevene får kjenne på gleden ved å lage produkter selv. Margun håper at elevene skal stimuleres til å arbeide videre med teknologi og design etter at de har fått en smakebit av emnet på ungdomsskolen. Hun nevner betydningen av skapende arbeid, f.eks. ved å bygge en bro, og viktigheten av at elevene får innsikt i teknikker for å konstruere byggverk. Kanskje noen vil inspireres til å ta en ingeniørutdannelse? Margun og Leif sine refleksjoner rundt planlegging og gjennomføring av teknologi og design, kan sies å være tett opp til hva jeg tolker som noe av kjernen ved emnet (KUF, 2004a, 2004b; UFD, 2003).

\section{Hvilken undervisning gjennomføres?}

Elevene til tre av informantene får praktiske konstruksjonsoppgaver i teknologi og design, mens to av informantene arbeider teoretisk med tematikken. I undervisningen til Margun og Gudmund har elevene brukt papir som byggemateriale. Margun lot elevene bygge forskjellige modeller av papirfly. De brukte ulik styrke (tykkelse) på papiret og så skulle elevene avgjøre hvilke fly som svevde lengst gjennom en konkurranse i klassen. Elevene til Margun brukte også sammenrullet papir til å lage ulike byggverk. Papirrullene ble føyet sammen av stifter og så skulle elevene undersøke hvilke byggverk som var sterkest. Læringsaktivitetene er relevante for teknologi og design, i tråd med kompetansemålene for ungdomstrinnet (KD, 2006, s. 90), og samsvarer med oppfatninger om teknologisk kunnskap (Dakers, 2007; McCormick, 1997). Elevene til Gudmund lagde en bro av papirark i åttende klasse. Den skulle være $10 \mathrm{~cm}$ bred og minimum $50 \mathrm{~cm}$ lang, og så var det konkurranse mellom elevene 
hvilken bro som var sterkest. Det ble avgjort ved å feste en korg under broen og fylle denne med halvliters vannflasker til broen raste sammen. Inntrykket mitt er at papir ofte brukes som byggemateriale, noe som kan begrense elevers opplæring i materialkunnskap. Bygging med papir kan illustrere prinsipper for konstruksjon og er trolig en arv fra prosjektet Teknologi i Skolen (NITO og RENATE senteret). Ifølge Gudmund gir konkurransen god stemning i klassen. Elevene arbeider i grupper og de bruker tre fire timer på å lage broen. Han uttrykker at «man lærer gjennom å gjøre og så har man et bra utgangspunkt for å lære mer». Gudmund merker at prosjektet skaper glede blant elevene og de motiveres til å gå dypere inn i fysikkrelaterte problemstillinger knyttet til brobygging. Han ønsker at prosjektet skal vise elevene hvorfor vi lærer naturfag, og at kunnskapen trengs for å løse utfordringer i samfunnet. Gudmund tilkjennegir en utstrakt refleksjon over nytteverdien av kunnskap i teknologi og design (Banks, 1996).

Leif arbeider ved en skole hvor elever i åttende klasse bygger med robolego, og han arrangerer en konkurranse om å konstruere den raskeste bilen. Det er noe forskjell mellom lærerne ved hans skole hvordan de gjennomfører denne undervisningen, og informanten nevner at andre lærere legger mer vekt på programmering av bilene med datamaskin. Margun sier hun også kunne tenkt seg å bygge bil sammen med elevene, men begrenses av lite utstyr og svak økonomi ved skolen. Margun forteller videre om en kollega med samme ønske som henne, som brukte mye fritid og egne penger til å kjøpe utstyret skolen manglet. Dette er en praksis for å realisere undervisning på som hun stiller spørsmål ved. Johan informerer om at elever ved hans skole har laget modellbiler og hatt bilrace i kunst og håndverk (Johan var ikke involvert i dette). Elevene designet og laget bilene av hardplast med strikkmotor. Denne oppgaven ser ut til å være spennende og relevant i teknologi og design, da læringsarbeidet inneholder utvikling av design for å løse utfordringer knyttet til bilens funksjonalitet.

Vi skal se nærmere på hvordan elevene gjennomførte oppgavene. Elevene som konstruerte bil av robolego startet idéutvikling basert på gruppemedlemmene sine tegninger. Elevene presenterte tegningene for hverandre og så valgte gruppen en skisse som grunnlag for byggingen. Årsaken til at Leif lot elevene arbeide i grupper forklares med knapphet på lego og et ønske om at elevene skulle lære seg å samarbeide. Han tror heller ikke elevene hadde greid å få til like mye dersom de hadde arbeidet individuelt. Til slutt skulle elevene ha en presentasjon hvor de dokumenterte prosessen med skisser og bilder, og det skulle komme frem hva som gikk bra og hva som måtte utbedres. Margun krever også at elevene skal presentere det de har laget og så pleier de å ha en utstilling av produktene. Elevene hennes skriver deretter en rapport om utviklingen av produktet som vurderes av lærer. Undervisningen som Leif og Margun beskriver synes å gi elevene muligheter til å utvikle relevante erfaringer med teknologi og design. Læringsarbeidet har fokus på design, produktene krever teknologiske løsninger, og elevene deler erfaringer fra prosjektet. Disse to lærerne realiserer en god del av den ideologiske og formelle læreplanen (Goodlad et al., 1979) sine beskrivelser av teknologi og design. Aktivitetene ligger endatil tett opptil kompetansemål i både naturfag og kunst og håndverk (KD, 2006, s. 90 og s. 134), selv om det ikke var planlagt som tverrfaglig undervisning.

Leif synes de sentrale føringene er tydelige på at «elevene skal være utprøvende selv, at det ikke er alt for styrt med hvordan de skal gjøre det». Målet for læringsarbeidet skal være klart, men veien frem bør være åpen og mindre lærerstyrt. Inntrykket fra denne studien er at det varierer hvor egnet oppgavene er for elevene til å sette sitt preg på prosessen og produktet, da mange oppgaver er utformet som en oppskrift. Denne observasjonen støtter en tidligere undersøkelse av norsk læremateriell i teknologi og design (Austestad \& Lutnæs, 2009).

To av informantene, Oscar og Johan, lar ikke elevene få praktiske oppgaver i teknologi og design, noe som er overraskende på bakgrunn av omtalen hovedområdet får i LKo6 og gjeldende kompetansemål for ungdomsskolen (KD, 2013). Johan sier det gjøres lite i teknologi og design i naturfag ved skolen hans, og han pleier å samtale med elevene om kriterier som stilles til en brokonstruksjon. Det er lite som tyder på at elevene har andre læringsaktiviteter enn den lærerstyrte samtalen. Johan begrunner sitt valg ved at han savner tid til undervisning i teknologi og design, for det er så mange emner en skal gjennom før eksamen i 10. klasse. Ludvigsen-utvalget bemerker at flere fag i norsk grunnskolen er for 
brede og bør slankes for å gi mer dybdelæring. I læringsforskningen er det også økende konsensus om dybdelæring sin betydning for elevers faglige fremgang (KD, 2014; NRC, 2000). Oscar sier uinspirert at elevene er mottakere av undervisning i teknologi og design. På spørsmål om hvordan han synes undervisningen fungerer er svaret at «du kan si den preges vel $i$ noen grad av pliktløp» (Oscar). Informanten lar meg vite at han ikke kjenner seg kompetent på området og han oppfattes dithen at teknologi og design skulle han helst slippe å undervise.

\section{Tverrfaglig undervisning}

Stortingsmeldingen Kultur for læring (KUF, 2004a) beskriver teknologi og design som et tverrfaglig emne. Ble det slik? Ingen av informantene i denne studien samarbeider med kunst og håndverk eller matematikk om konkret undervisning. Flere ganger under intervjuene uttrykker informantene at de ønsker undervisning sammen med kunst og håndverk, men lite tid til planlegging, og det jeg oppfatter som tette skott mellom fagene, hindrer samarbeid.

Hvert fag har sin tilnærming til dette emnet [teknologi og design, min tilføyelse]. Det er ikke noe felles prosjekttid (Johan)

En annen informant svarer følgende på spørsmål om hvordan tverrfagligheten i teknologi og design ivaretas: «Det er fraværende» (Gudmund). Margun sier også at det er lite tid til planlegging sammen med naturfagslærerne på trinnet, og Oscar vet ikke engang hva de andre naturfaglærerne, ved samme ungdomsskole, gjør i teknologi og design. Han har ikke spurt og kollegene har ikke fortalt.

\section{AVSLUTTENDE DISKUSJON OG KONKLUSJON}

Informanter i denne studien oppfatter at skolemyndighetene sin intensjon med teknologi og design er at elevene skal øke sin kompetanse i teknologi og realfag for å dekke behov i samfunnet. Informantene deler også en oppfatning at elever skal motiveres til å trenge dypere inn i naturfaget og velge en utdanning innen realfag. I Sverige erfarte en at mange unge flyktet fra naturvitenskap og tekniske studier og myndighetene innførte teknikk i grunnskolen for å motvirke den utviklingen (Riis, 2013).

Det fremheves også at økt kompetanse på teknologi og design er nødvendig for å skape nye arbeidsplasser i Norge. NITO Prosjektet Teknologi i Skolen skulle løfte teknologi, styrke naturfagene i grunnskolen og bidra til fremtidig verdiskaping (Hansen, 2007). I årene frem mot innføringen av LKo6 ble høykonjunkturen i Norge i økende grad merkbar og etterspørselen av teknisk kompetanse steg. Samfunnsutviklingen ryddet altså veien for en læreplan som skulle bidra til at teknologi ble en del av allmenndannelsen (Hansen, 2010).

Denne studien viser at lærerne har en oppfattelse av hensikten med teknologi og design som i stor grad sammenfaller med skolemyndighetene sine ønsker (KUF, 1993, 2004a, 2004b; UFD, 2003). Informanter peker på nasjonale økonomiske- og fagpolitiske interesser som en ideologisk årsak bak innføringen av teknologi i norsk skole. Forskjeller som registreres er at informantene er lite opptatt av at emnet er et tiltak mot synkende naturfagskompetanse (UFD, 2003). Produktfokuset i LKo6 vektlegges heller ikke så sterkt, og de kulturelle argumenter for teknologi făr ikke oppmerksomhet (Bungum, 2006; KD, 2013).

Lærerne henter materiell til egen undervisning fra flere kilder som læreverk og nettressurser. Men, kompetansemålene i LKo6 synes å være mindre styrende for læringsarbeidet til elevene, særlig de som ikke direkte dreier seg om bygging og testing av produkter. Tre av lærerne lar elevene bygge konstruksjoner eller fremkomstmidler, og det konkurreres i styrke og hurtighet. Bruk av robolego gir fine muligheter for programmering, som er relevant i forhold til kompetansemål for teknologi og design på ungdomstrinnet (KD, 2006, s. 90). Det krever imidlertid prioritering av innkjøp og opplæring av lærere for god bruk i undervisning. Programmering tydeliggjøres og får større rom i den nye læreplanen som innføres i 2020 (Udir, 2019), siden det er økende etterspørsel etter den kompetansen i samfunnet. 
Bygging er elevarbeid som er i tråd med LKo6, men for å innfri intensjoner og potensialet med emnet (Bungum, 2006; Esjeholm, 2015), må bredden på oppgaver i skolen være større enn bygging med lego og papir etter en oppskrift. Oppgaver utformet som en oppskrift har ofte få eller ingen frihetsgrader og det begrenser kreativt arbeid (Esjeholm, 2015). Kreativitet er sentralt i design, og avgjørende for å løse teknologiske utfordringer best mulig (Dahlin et al., 2013).

Det er interessant å merke at konkurranseaspektet skaper glød og kan tenne en gnist for videre læring i realfag. Teknologi og design inviterer også til gruppearbeid som utløser kreativitet og skaperglede hos elevene. Men, jeg savner et tydeligere fokus på hva elevene konkret skal lære gjennom arbeidet med emnet. To lærere nedprioriterer teknologi og design og velger lærerstyrt undervisning, uten praktiske aktiviteter. De representerer muligens en gruppe som har mindre kjennskap til aktuell undervisning, og som lar stofftrengselen i naturfag skyve emnet ut på sidelinjen. Resultatene i denne studien avdekker også en mangel på kompetanse for å undervise i teknologi. Det er en utfordring som må løses for å dyktiggjøre lærere til å ivareta teknologiemnet som ser ut til å bli en tydelig del av naturfaget fra 2020 (Udir, 2019).

Den største mangelen som avdekkes i undersøkelsen er det totale fraværet av tverrfaglig undervisning som sammenfaller med tidligere observasjoner (Dundas, 2011). Det er tankevekkende at ingen av informantene gjennomfører tverrfaglig undervisning slik LKo6 beskriver (KD, 2013) og som er tydelig uttrykt i bakgrunnsdokumentene for læreplanen (m.a. KUF, 2004a; UFD, 2003). Informantene kan heller ikke opplyse om annen tverrfaglig undervisning i teknologi og design ved den skolen de arbeider. Hovedforklaringen fra lærerne i denne studien, at det er knapt med tid til samarbeid, støtter funn som Dundas (2011) gjorde. Dundas mener lærerne selv må bedre situasjonen ved organisatoriske grep og prioritere fagovergripende undervisning (Dundas, 2011). I en hektisk skolehverdag blir dette som å løfte seg selv etter håret. Basert på informasjon fra lærerne i denne studien er mitt synspunkt at det må iverksettes tydelige og forpliktende endringer for å planlegge og gjennomføre tverrfaglig undervisning. Skoleledelsen må trolig pålegges å avsette tid til samarbeid mellom lærere som er ansvarlige for fagovergripende undervisning i teknologi og design. Lange tradisjoner med enfaglig undervisning i Norge (fra grunnskole til Universitet) kan også forklare vanskelighetene med å realisere tverrfaglighet i norsk grunnskole. Sannsynligvis må også lærerutdannelsen endres for å dreie den pedagogiske praksisen mot mer og bedre tverrfaglig undervisning som ønskes i fremtidens skole (KD, 2015).

Gapet mellom læreplanfestet tverrfaglig undervisning (KD, 2013), og virkeligheten slik den beskrives i denne studien, gir grunn til uro for at situasjonen i grunnskolen er værre enn vi liker. Dette bør undersøkes nærmere, for å danne seg en bedre forståelse av i hvilken grad det er mulig å realisere en ny læreplan fra 2020, med økt omfang av tverrfaglig undervisning (Udir, 2019). Trolig må en dyptgripende endring i skolen følge innføringen av ny læreplan. Erfaring med teknologi og design i norsk skole tilsier at en læreplanendring alene er langt fra tilstrekkelig for å legge til rette for tverrfaglighet.

\section{REFERANSER}

Almendingen, S. F., Klepaker, T., \& Tveita, J. (2003). Det bortkomne faget. Naturfaget tilbake i norsk grunnskole, Synteserapport for prosjektet: Natur- og miljøfag etter Reform 97, en evaluering ut fra et elevperspektiv. Høgskolen i Nesna.

Austestad, A., \& Lutnæs, E. (2009). Tilnærminger til teknologi og design i grunnskolen. FORMakademisk, 2(1), 60-69.

Banks, F. J. R. (1996). Approaches and models in technology teacher education: an overview. The Journal of Design And Technology Education, 1(3), 197-211.

Bungum, B. (2006). Teknologi og design i nye læreplaner i Norge: Hvilken vinkling har fagområdet fătt i naturfagplanen?. NorDiNa, 2(2), 28-39. doi: 10.5617/nordina.422

Dakers, J. R. (2007). Incorporating Technological Literacy into Classroom Practice. In M. d. Vries, R. Custer, J. R. Dakers \& G. Martin (Eds.) Analyzing Best Practices in Technology Education 
(pp. 125-137). Rotterdam: Sense Publishers.

Dahlin, L. K., Svorkmo, A.-G., \& Voll, L. O. (2013). Teknologi og design i skolen. Oslo: Cappelen Damm Akademisk.

Dundas, A. A. (2011). Hva skjedde med teknologi i skolen? En studie av læreres erfaringer med teknologi og design i grunnskolen (Master thesis, NTNU). Retrieved April 24, 2018 from BIBSYS Web site: https://brage.bibsys.no/xmlui/bitstream/handle/11250/270256/445928_FULLTEXT01.pdf?sequence $=1$ \&isAllowed $=\mathrm{y}$.

Ekeland, P. R., Hesenget, A.-B., Johansen, O.-I., Rygh, O., \& Busengdal Strand, S. (2006-2008). TELLUS Naturfag for ungdomstrinnet. Oslo: Aschehoug.

Esjeholm, B.-T. (2015). Design knowledge interplayed with student creativity in D\&T projects. International Journal of Technology and Design Education, 25(2), 227-243. doi: 10.1007/s10798014-9280-1

Fensham, P. J., \& Gardner, P. L. (1994). Technology education and science education: A new relationship? In D. Layton (Ed.) Innovations in science and technology education (pp. 159-170). Vol. 4. Paris: UNESCO.

Finans- og tolldepartementet (FT). (1993). Langtidsprogrammet 1994-1997. Oslo: Finans- og tolldepartementet.

Fontana, A., \& Frey, J. H. (2000). From structured questions to negotiated text. In N. K. Denzin \& Y. S. Lincoln (Eds.) Handbook of Qualitative research (pp. 645-672). Thousand oaks: Sage publications Inc.

Ginner, T., \& Mattsson, G. (1996). Teknik i skolan: perspektiv på teknikämnet och tekniken. Lund: Studentlitteratur.

Goodlad, J. I., Klein, M. F., \& Tye, K. A. (1979). The Domains of Curriculum and Their Study. In J. I. Goodlad (Ed.) Curriculum Inquiry. The Study of Curriculum Practice (pp. 43-76). New York: McGraw-Hill Book Company.

Gustafsson, P., Jonsson, G., \&Nilsson, T. (2018). Teknikämnet i svensk grundskolas tidliga skolår sett genom forskningscirkelns lupp. NorDiNa, 14(2), 113-124. doi: 10.5617/nordina.6161

Hansen, P. J. K. (2007). Teknologi og design Hva Hvorfor Hvordan: Et fagdidaktisk veiledningshefte (2. utg.). Oslo: Høgskolen i Oslo.

Hansen, P. J. K. (2010). Teknologi og design i grunnskolen: Veien fra ideologisk mulighet i 1993 til flerfaglig område i 2006. In L. O. Voll \& P. J. K. Hansen (Eds.) Intensjon og praksis i teknologi og design: En studie av noen utvalgte prosjekter (pp. 7-32). Oslo: Høgskolen i Oslo.

Harlen, W. (2015). Working with Big Ideas of Science Education. Trieste: The Science Education Programme (SEP) of IAP.

Hodgson, J., Rønning, W., \& Tomlinson, P. (2012). Sammenhengen mellom undervisning og læring. En Studie av læreres praksis og deres tenkning under kunnskapsløftet. Sluttrapport. Bodø: Nordlandsforskning.

Jones, A., Buntting, C, \& de Vries, M. J. (2013) The developing field of technology education: a review to look forward. International journal of Technology and Design Education, 23, 191-212. doi: 10.1007/s10798-011-9174-4

KUF. (1993). Læreplan for grunnskole, videregående opplæring og voksenopplæring-Generell del (L93). Retrieved April 24, 2018 from the Norwegian Directorate for Education and Training Web site: https://www.udir.no/upload/larerplaner/generell_del/generell_del_lareplanen_ bm.pdf.

KUF. (1996). Læreplanverket for den 10-årige grunnskolen (L97). Retrieved April 24, 2018 from the National Library of Norway Web site: http://www.nb.no/nbsok/nb/f4ce6bfgeadeb389172d 939275co38bb?lang=no\#o.

KUF. (2004a). Stortingsmelding nr. 30 (2003-2004) Kultur for læring. Retrieved April 24, 2018 from the Government Web site: https://www.regjeringen.no/contentassets/988cdbo18ac24ebo aocf95943e6cdb61/no/pdfs/stm20032004003000odddpdfs.pdf.

KUF. (2004b). Innst. S. nr. 268 (2003-2004) Innstilling fra kirke-, utdannings- og forskningskomiteen om kultur for læring. Retrieved April 24, 2018 from the Parliament Web site: https:// 
www.stortinget.no/globalassets/pdf/innstillinger/stortinget/2003-2004/inns-200304-268. pdf.

Kunnskapsdepartementet (KD). (2006). Læreplanverket for Kunnskapsløftet. Oslo: Kunnskapsdepartementet.

Kunnskapsdepartementet (KD). (2013). Læreplanverket for Kunnskapsløftet. Retrieved April 24, 2018 from the Norwegian Directorate for Education and Training Web site: https://www.udir. no/laring-og-trivsel/lareplanverket/hvordan-er-lareplanene-bygd-opp/.

Kunnskapsdepartementet (KD). (2014). Elevenes læring i fremtidens skole. Et kunnskapsgrunnlag (NOU 2014: 7). Retrieved April 20, 2018 from the Government Web site: https:// www.regjeringen.no/contentassets/e22a715fa374474581a8c58288edc161/no/pdfs/ nou201420140007000dddpdfs.pdf.

Kunnskapsdepartementet (KD). (2015). Fremtidens skole - Fornyelse av fag og kompetanser (NOU 2015:8). Retrieved April 16, 2018 from the Government Web site: https:// www.regjeringen.no/contentassets/da148fec8c4a4ab88daa8b677a700292/no/pdfs/ nou2015201500080oodddpdfs.pdf.

Kunnskapsdepartementet (KD). (2016). Stortingsmelding nr. 28 (2015-2016) Fag - Fordypning - Forståelse. En fornyelse av Kunnskapsløftet. Retrieved April 16, 2018 from the Government Web site: https://www.regjeringen.no/contentassets/e8e1f41732ca4a64boo3fca213ae663b/ no/pdfs/stm2015201600280oodddpdfs.pdf.

Kunnskapsdepartementet (KD). (2018). Kjerneelementer i fag. Retrieved January 25, 2019 from the Government Web site: https://www.regjeringen.no/no/aktuelt/fornyer-innholdet-i-skolen/id2 606028/?expand=factbox2606058.

Kvale, S., \& Brinkmann, S. (2009). Det kvalitative forskningsintervju (2. utg.). Oslo: Gyldendal akademisk.

Lokus (n.d.). Retrieved April 16, 2018, from www.lokus.no/8-10

McCormick, R. (1997). Conceptual and Procedural Knowledge. International journal of Technology and Design Education, 7(1-2), 141-159. doi: 10.1023/A:1008819912213

National Research Council (NRC). (2000). How people learn. Brain, mind, experience and school. Expanded Edition. Washington D.C.: National Academy Press.

Naturfagsenteret (n.d). Retrieved April 24, 2018, from www.naturfagsenteret.no.

Riis, U. (1996). Kan man äga ett skolämne-dragkampen om tekniken. In T. Ginner \& G. Mattsson (Eds.) Teknik i skolan: perspektiv på teknikämnet og tekniken (pp. 41-52). Lund: Studentlitteratur.

Riis, U. (2013). Teknik-mellan slöjd och naturvetenskap. In J. Hallström \& C. Klasander (Eds.) Ginners teknikdidaktiska handbok (pp. 100-114). Norrköping: Linköping University.

Sanne, A. et al. (2016). Teknologi og programmering for alle. En faggjennomgang med forslag til endringer i grunnopplæringen. Oslo: Udir.

Sjøberg, S. (1994). Naturfagutredningen, del I. Oslo: Nasjonalt læremiddelsenter.

Sjøberg, S. (2009). Naturfag som allmenndannelse - en kritisk fagdidaktikk (2. utg.). Oslo: Gyldendal Akademisk.

Skolinspektionen. (2014). Teknik - gör det osynliga synligt. Om kvaliteten i grundskolans teknikundervisning (2014:04). Retrieved February 06, 2019, from http://www.skolinspektionen.se/ sv/Beslut-och-rapporter/Publikationer/Granskningsrapport/Kvalitetsgranskning/Teknik--gordet--osynliga-synligt/.

Transana versjon 2.42 (n.d.). Retrieved April 10, 2018, from www.transana.org/about/news.htm.

Tveitereid, M. (1997). Matematikk, naturvitenskap, teknologi: tiltak for å styrke disse fagområdene i norsk utdanning. Sluttrapport. Oslo: KUF.

Utdanningsdirektoratet (Udir). (2012). Evaluering av Kunnskapsløftet. 2006-2012. Utdanningsdirektoratets oppsummering av evalueringen. Retrieved April 24, 2018 from the Norwegian Directorate for Education and Training Web site: https://www.udir.no/Upload/Rapporter/ EVAKL_presentasjoner_sluttrapporter/UDIR_Evaluering_Kunnskapsloeftet_2012_korr3. pdf?epslanguage $=$ no. 
Utdanningsdirektoratet (Udir). (2019). Forslag til nye læreplaner. Retrieved April 01, 2019 from the Norwegian Directorate for Education and Training Web site: https://www.udir.no/laringog-trivsel/lareplanverket/fagfornyelsen/horing-nye-lareplaner/.

Utdannings- og forskningsdepartementet (UFD). (2002). Realfag, naturligvis - strategi for å styrke realfagene 2002-2007. Oslo: Statens forvaltningstjeneste.

Utdannings- og forskningsdepartementet (UFD). (2003). I første rekke - Forsterket kvalitet $i$ en grunnopplæring for alle (NOU 2003: 16). Retrieved April 24, 2018 from the Government Web site: https://www.regjeringen.no/contentassets/37a02a7bd6d94f5aacd8b477a3a956f3/no/ pdfs/nou20032003001600odddpdfs.pdf.

Utdannings- og forskningsdepartementet (UFD). (2005). Realfag, naturligvis - strategi for å styrke realfagene 2002-2007. Retrieved April 24, 2018 from the Government Web site: https://www.regjeringen.no/globalassets/upload/kilde/ufd/rap/2002/o013/ddd/ pdfv/235427-realfag.pdf. 